\title{
Green entrepreneurship intention in university students: The case of Peru
}

\author{
Aldo Alvarez-Risco, Sabina Mlodzianowska, Ulises Zamora-Ramos, \\ Shyla Del-Aguila-Arcentales
}

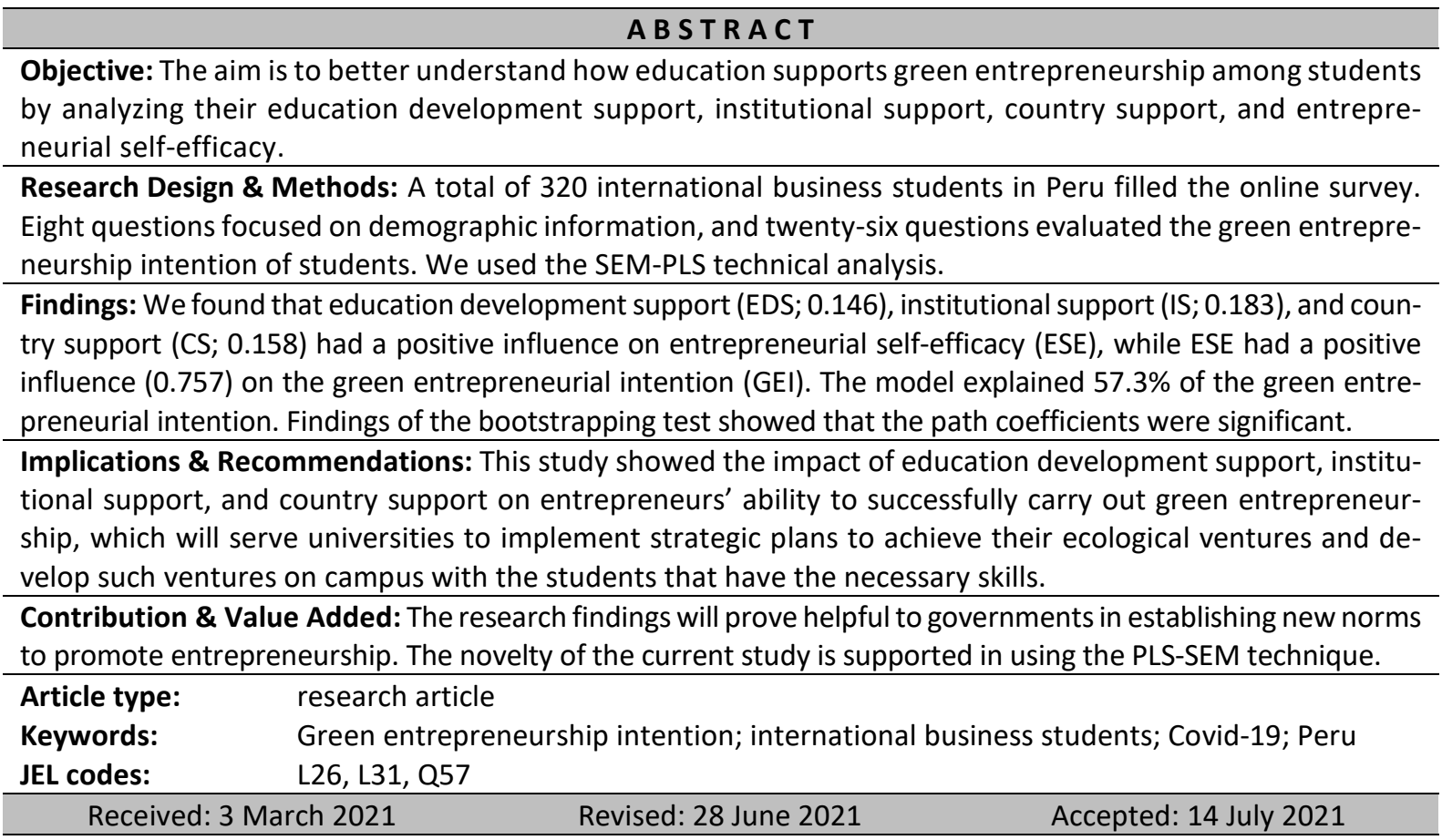

\section{Suggested citation:}

Alvarez-Risco, A., Mlodzianowska, S., Zamora-Ramos, U., Del-Aguila-Arcentales, S. (2021). Factors of green entrepreneurship intention in international business university students: The case of Peru. Entrepreneurial Business and Economics Review, 9(4), 85-100. https://doi.org/10.15678/EBER.2021.090406

\section{INTRODUCTION}

Entrepreneurship is continuously growing in recent years, and it has diversified its proposal for new values as green entrepreneurship. Some reports described outcomes of learning and development activities focused on entrepreneurship (Lamont, 1972). Suffice it to mention the initial university experiences of entrepreneurship in Canada (Hay, 1981). There, the scholars identified the weaknesses of university education regarding the knowledge and skills necessary for entrepreneurship, along with identifying the role of universities in promoting business development from theoretical and practical academic training (Segal, 1986), which is to give added value to universities (McMullan, Long, \& Graham, 1986). Thus, university education has been seen to gradually orient more towards entrepreneurship (Hills, 1988; Hopkins, \& Feldman, 1989).

Entrepreneurship has grown and has been seen as an alternative for personal development, even associated with personal survival. In this way, we may argue that the aspects that impact society trigger different actions of people. Since the beginning of 2020, we could have observed the beginning of a new 
global social dynamic. The Covid-19 pandemic dramatically changed people's lives and businesses, causing 3.7 million people to die as of 5 June 2021 (WHO, 2021). This pandemic has led to significant damages among health professionals (Chen et al., 2020; Yáñez, Afshar Jahanshahi, Alvarez-Risco, Li, \& Zhang, 2020; Zhang et al., 2021; Zhang et al., 2020), population behaviour (Aldo Alvarez-Risco, Mejia, et al., 2020; Quispe-Cañari et al., 2021; Yáñez, Alvarez-Risco, \& Delgado-Zegarra, 2020), population education (Aldo Alvarez-Risco et al., 2021; Aldo Alvarez-Risco, Estrada-Merino, Anderson-Seminario, et al., 2020), firms (A. Alvarez-Risco, Del-Aguila-Arcentales, \& Diaz-Risco, 2018; Aldo Alvarez-Risco, Estrada-Merino, \& Perez-Luyo, 2020; Yan et al., 2021), and finally, the global economy (Ashraf, 2020; Laing, 2020).

During this Covid-19 pandemic, many people lost their jobs, which created severe problems for families with insufficient resources to survive. In this situation, some studies seek to obtain information from students regarding the intention of entrepreneurship that would meet the social demand for more jobs if implemented logically. In this sense, recent studies investigate entrepreneurship variables in times of the Covid-19 pandemic (cf. Liguori \& Winkler, 2020).

The novelty of this study is that globally, the universities seek to promote entrepreneurship among their students, and today, intergovernmental organizations are encouraged to develop activities based on United Nations' Sustainable Development Goals (SDG). It is very important for universities and policymakers to know which factors influence green entrepreneurship to elaborate green entrepreneurship programs for their students.

We should learn if universities offer elective courses on entrepreneurship, which shows students' knowledge about it; likewise, we should learn if the universities promote entrepreneurship through the implementation of projects, workshops, postgraduate courses, and conferences. On the other hand, we should learn if the universities connect students with entrepreneurs, create awareness about entrepreneurship, provide knowledge, and motivate students to be entrepreneurial. Finally, we should learn what students think about their country's support for green entrepreneurship, whether they are encouraged by any state proposal, if the government offers opportunities through programs to promote green entrepreneurship, and does it facilitate bank loans necessary to start the green business. In this sense, we should also learn whether students can develop an ecological enterprise today or in the future.

Therefore, we seek to better understand how education supports green entrepreneurship among students by analyzing their education development support, institutional support, country support, and entrepreneurial self-efficacy.

The following section will describe the literature review and then the hypotheses development. Next, we will detail the methodology, results, and discussion. Finally, the article ends with conclusions, along with theoretical and practical implications.

\section{LITERATURE REVIEW AND HYPOTHESES DEVELOPMENT}

The experiences of training in entrepreneurship at universities were reported from different countries. Thus, we can recognize initial reports of entrepreneurship in universities. Initially, Huu-Phuong and SooJiuan (1990) foreground the importance of SMEs in technological innovation and their entrepreneurial spirit, thus highlighting the advantage of small-scale to respond more quickly to variations in the market. Interviews with 1200 exporters in the manufacturing and services sectors showed the intentions of sustainable ventures that would open up new markets. Through empirical research, Johannisson (1991) evidence that social skills are relevant to promote entrepreneurial activities; likewise, he finds that entrepreneurial education requires an approach that considers social, personal, and organizational resources. Chrisman, Hynes, and Fraser (1995) evaluate business activities at the University of Calgary to find that around 100 start-ups began because of significant contributions from professors, generating new job positions; likewise, it was projected that approximately 14 companies would be created in short-term. Dill (1995) measures the management and perceived performance effectiveness by evaluating patent and licensing offices to recognize the great importance of all these units in the support of entrepreneurship from universities. Dill also mentions that governments have a crucial role in promoting the development of these strategic units. Tamkivi (1999) describes the successful transfer of university-developed technologies. Klofsten and Jones-Evans (2000) report some teachers' actions involved with industrial and 
commercial industry in Sweden and Ireland. Their results show considerable business experience among academics, which translates into consulting activities, although not the creation of technological spinoffs. Udayanan (2019) studies entrepreneurial intention among 263 university graduates, taking self-efficacy for a mediator variable, evaluated with the AMOS software. We find that the ESE mediates the effect of self-efficacy on GEI. The above research is helpful for the formulation of public policies and for university authorities that promote the development of sustainable entrepreneurship courses.

\section{Variables}

\section{Green entrepreneurial intention (GEI)}

The green entrepreneurial intention could be understood as a situation or state of the individual that generates interest, attention, and decision to implement a specific action (Bird, 1988; Meoli, Fini, Sobrero, \& Wiklund, 2020; Santos Susana \& Liguori Eric, 2019). The intention to act contains different motivating factors that directly influence the behaviour, as indicated by the TPB (Fishbein \& Ajzen, 1975). Intention is the step preceding behaviour. Studies show that entrepreneurship's intention positively influences the materialization of entrepreneurship (Meoli et al., 2020; Neneh, 2019; Rauch \& Hulsink, 2015). This study considers the intention to develop green entrepreneurship by university students.

Scholars can identify investigations that focus on different variables that affect green entrepreneurship. Bonnet, Quist, Hoogwater, Spaans, and Wehrmann (2006) show that we can establish a combination of education in projects, sustainability, and entrepreneurship among engineering students. They mention a mode of integration of sustainability and entrepreneurship by moving from the idea to analysing context, marketing, production, and financing. Moreover, they evaluate the results of the reported start-ups and the learning outcomes of professors and students. Futagami and Helms (2009) describe that an economical solution to reverse the financial challenges is the development of entrepreneurship, which they report as increasing in Japan outside of traditional business development systems, without ties to business unions and the country's culture, which usually promotes entrepreneurship, group counselling, and a low-risk approach. Banschbach and Letovsky (2011) recount the experience of natural science students teaching environmental science concepts to senior entrepreneurs, while entrepreneurs taught natural science students the aspects of business development. Campelo Rodríguez (2013) describe the results of two projects on the acquisition of entrepreneurial skills in which they studied the professional, social, and green entrepreneurship profiles of 72 students. Opara (2013) recognizes that promoting entrepreneurship programs is necessary to take advantage of innovative technologies to increase productivity and university knowledge. There is evidence that these green entrepreneurship efforts will positively impact the emergence of sustainable agriculture in Africa. Soomro, Ghumro, and Shah (2020) seek to establish the preference of developing green entrepreneurship among 284 university students of business management and entrepreneurship courses. The authors recognize the effect of an orientation towards sustainability and the effect of education for creating an inclination to green entrepreneurship. These data are of great value for the government and university authorities as it shows the need to create awareness programs and, at the same time, adapt curricula to incorporate training about green entrepreneurship. Nguyen (2020) evaluates factors on entrepreneurial intention among $635 \mathrm{stu}-$ dents in 11 universities by using the SEM PLS to analyse data and to find the effect of perceived environmental factors on students' perceived entrepreneurial behavioural control.

This study used the theory of planned behaviour (TPB) as a theoretical approach to determine the influence of contextual factors and self-efficacy on the intention of green entrepreneurship. The TPB was first proposed by Fishbein and Ajzen (Fishbein \& Ajzen, 1975) to explain that people's intentions follow certain factors which also convey confidence to face an activity, described as self-efficacy. Likewise, the TPB includes intention as a strong predictor of behaviour, which in our study implied that if students receive support from a country's regulations for green entrepreneurship, they will have the self-efficacy to develop green entrepreneurship, and finally, the intention to implement green entrepreneurship.

Moreover, this study used the theory of social cognition. Bandura (1986) was the one to develop this theory to emphasize that behaviours are within the individual's control. We know it also as self- 
efficacy. There is a two-way relationship between environmental aspects, personal factors, and behaviour. These aspects are reflected in the development of motivations to undertake entrepreneurship, educational support for green entrepreneurship, and the legislation that facilitates these undertakings.

\section{Education development support (EDS)}

Education development support is understood as the set of training activities offered by the university to develop enterprises (Bergmann, Geissler, Hundt, \& Grave, 2018). We expect that the educational support will focus on offering compulsory courses or elective courses that can help to understand how to develop ventures, carrying out practical projects to learn the implementation and development of ventures. On the other hand, the educational support focuses on offering pre-professional internships in organizations concentrated on entrepreneurship. It is even related to the offer of professional career or postgraduate studies that may be linked to entrepreneurship content. We measured whether conferences and practical workshops were held to develop competencies and obtain more knowledge about entrepreneurship, including linking students with real entrepreneurs. Education development support would influence self-efficacy for the development of ecological entrepreneurship, so we hypothesize that:

H1: Education development support has a positive influence on entrepreneurial self-efficacy.

\section{Institutional support (IS)}

Institutional support is understood as the efforts made by the university to provide new technical knowledge about entrepreneurship and thereby contribute to the generation of awareness about entrepreneurship in students - who upon graduation can develop successful ventures - by directly motivating students to form new business as professional development (Ferreira, Loiola, \& Guedes Gondim, 2017). Likewise, students generate new business ideas both in the social field and in the environmental field by assuming a business approach. Institutional support would influence self-efficacy for the development of ecological entrepreneurship, so we hypothesize that:

H2: Institutional support has a positive influence on entrepreneurial self-efficacy.

\section{Country support (CS)}

Country support is understood as a country's efforts to contribute to the development of ventures (Fichter \& Tiemann, 2018). In this way, we evaluated whether a students believed they are institutionally motivated to establish ecological enterprises in their country. Another evaluated aspect was whether students viewed their country's economy as offering many options for entrepreneurship, which can also be evidenced in their emotions and feelings about obtaining bank loans for the development of entrepreneurship. Specific laws would promote and make accessible the development of businesses, so we hypothesize that:

H3: Country support has a positive influence on entrepreneurial self-efficacy.

\section{Entrepreneurial self-efficacy (ESE)}

Self-efficacy is when one believes s/he can achieve success in an activity and incorporate specific behaviours into one's daily routine (Bandura, 1992; Krueger, Reilly, \& Carsrud, 2000). Specifically, ESE is one's confidence in developing entrepreneurial activities and thus generating business (Newman, Obschonka, Schwarz, Cohen, \& Nielsen, 2019; Shahab, Chengang, Arbizu Angel, \& Haider Muhammad, 2019). Studies show that there is a positive influence of ESE on the intention of entrepreneurial intention (Kumar \& Shukla, 2019; Li et al., 2020; Mei et al., 2017), which means that people with high self-efficacy - based on great confidence - are more likely to create new entrepreneurship activities. The same applies to green businesses, which are of great importance in the times of the Covid-19 pandemic (Tajvidi \& Tajvidi, 2020). Thus, we hypothesize that:

H4: Entrepreneurial self-efficacy has a positive influence on green entrepreneurial intention. 


\section{Research model}

Following previous literature, we established the relation of the variables recognized in the research model proposed to be tested (see Figure 1).

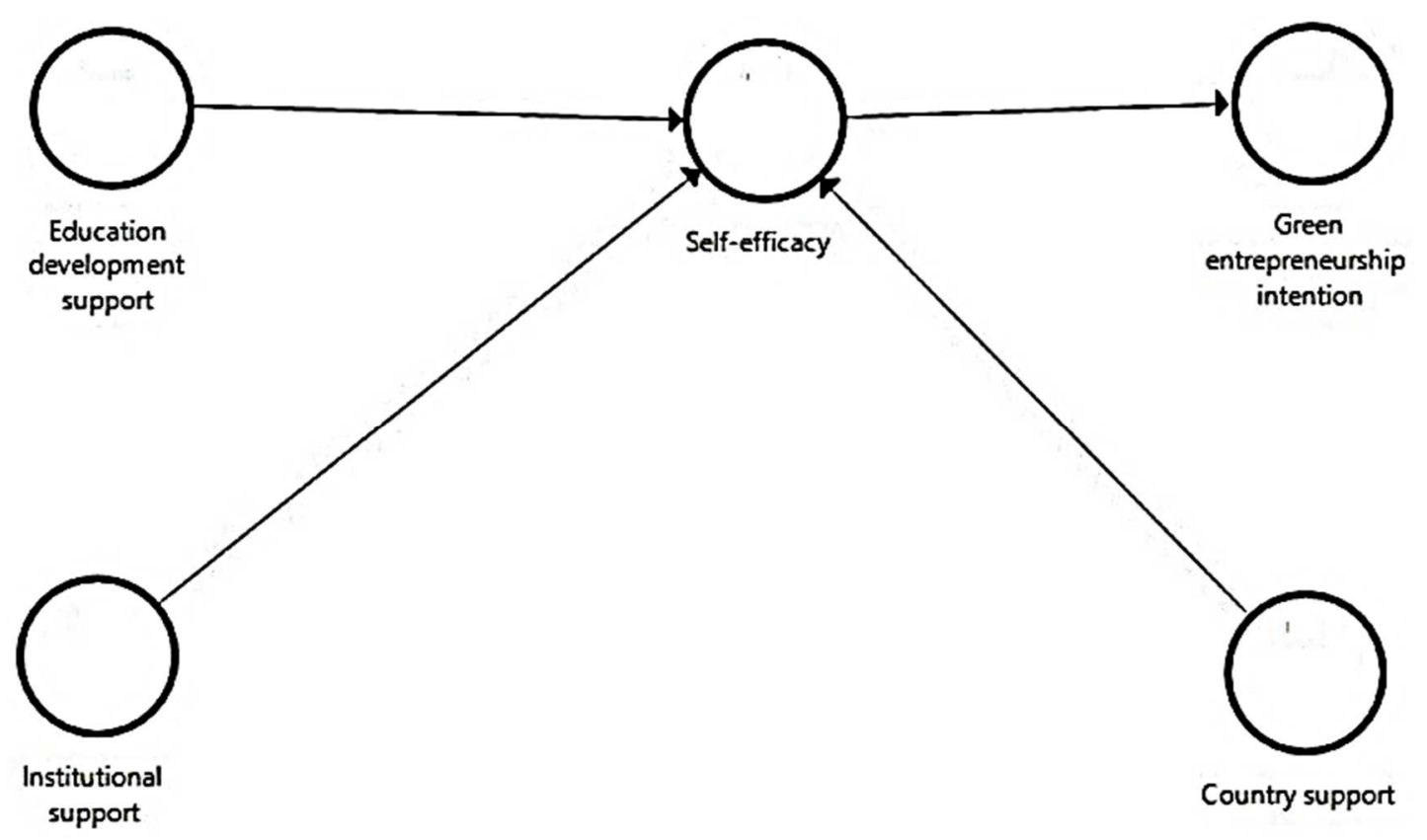

Figure 1. Research model

Source: own elaboration.

\section{RESEARCH METHODOLOGY}

\section{Sample and data collection}

We used the survey method to collect data from university students in Peru. The sampling was nonprobabilistic. We obtained the data via a questionnaire in Google Forms in 10-26 December 2020, which resulted in a sample of 320 university students. The collection of the data was implemented through the distribution to university students by emails and online chats. For ethical purposes, the questionnaire was applied to students that agreed to answer after reading the following statement: "Your participation is voluntary; therefore, the information obtained will be confidential and will only be used for research purposes." We did not ask for approval for the current research because it does not involve risks for participants. The questionnaires were completed by 177 men (55.31\%) and 143 women (44.69\%) aged 18-33 (mean: 21.68; SD: 3.07 years).

\section{Measures}

The six items for education development support (EDS) were adopted after Wegner, Teixeira, and Maehler (2019). The $\alpha$ was 0.937.

The four items for institutional support (IS) were adopted from Wegner et al. (2019), including its four items. The $\alpha$ was 0.930 . We included the four items for the measurement of country support (CS). The $\alpha$ was 0.795 .

The four items for entrepreneurial self-efficacy (ESE) were adopted from Soria-Barreto, ZúñigaJara, and Ruiz Campo (2016), including the four items. The $\alpha$ was 0.912 .

The eight items for green entrepreneurial intention (GEI) were adopted from Moriano (2005), Liñán and Chen (2009), and Wegner et al. (2020). The $\alpha$ was 0.945. We used a five-point Likert scale ranging from "strongly disagree" (1) to "strongly agree" (5). 


\section{Data analysis}

The PLS-SEM as a technique of analysis allows for the evaluation of structural models considering measurement errors. We used the SmartPLS software 3.3.2 for data analysis. The data analysis was initiated to evaluate the internal consistency of each subscale (Cronbach >0.707). Next, we analysed construct and discriminant validity and internal consistency (Ringle, Wende, \& Becker, 2015). A good fit requires the value of average extracted variance (AVE) to be higher than 0.5. We used the FornellLarcker criterion to test discriminant validity (Fornell \& Larcker, 1981).

\section{Reliability}

The scales showed Cronbach's alpha to be higher than 0.5 in an exploratory analysis (Lopez-Odar, Alvarez-Risco, Vara-Horna, Chafloque-Cespedes, \& Sekar, 2020; see Table 1).

Table 1. Evaluation of internal consistency

\begin{tabular}{|l|c|c|c|}
\hline \multicolumn{1}{|c|}{ Variables } & Items & $\begin{array}{c}\text { Alpha of Cronbach } \\
\text { values }\end{array}$ & $\begin{array}{c}\text { Range of } \\
\text { item values }\end{array}$ \\
\hline Education development support (EDS) & 6 & 0.937 & $0.832-0.898$ \\
\hline Institutional support (IS) & 4 & 0.930 & $0.868-0.932$ \\
\hline Country support (CS) & 4 & 0.795 & $0.751-0.830$ \\
\hline Entrepreneurial self-efficacy (ESE) & 4 & 0.912 & $0.858-0.918$ \\
\hline Green entrepreneurial intention (GEI) & 8 & 0.945 & $0.795-0.915$ \\
\hline
\end{tabular}

Source: own study.

\section{Validation and compound reliability}

The questionnaire validation using SEM-PLS based on an analysis developed by Lopez-Odar et al. (2020). The validation expected a value higher than 0.707 for acceptable composite reliability (Lopez-Odar et al., 2020). The coefficients of reliability composed oscillated between 0.867 and 0.954 (see Table 2).

Table 2. Construct validity evaluation

\begin{tabular}{|c|c|c|c|}
\hline Variables - Items & $\begin{array}{l}\text { Factorial } \\
\text { weight }\end{array}$ & $\begin{array}{l}\text { Compo- } \\
\text { site relia- } \\
\text { bility }\end{array}$ & AVE \\
\hline EDS (My university.......) & & \multirow{7}{*}{0.950} & \multirow{7}{*}{0.760} \\
\hline .... offers elective courses on entrepreneurship & 0.866 & & \\
\hline .... offers project work focused on entrepreneurship & 0.886 & & \\
\hline .... offers practices focused on entrepreneurship & 0.898 & & \\
\hline .... offers a bachelor's or master's degree study in entrepreneurship & 0.868 & & \\
\hline .... organize conferences/workshops on entrepreneurship & 0.879 & & \\
\hline .... connects students with entrepreneurs & 0.832 & & \\
\hline \multicolumn{2}{|l|}{ IS (My university.......) } & \multirow{5}{*}{0.950} & \multirow{5}{*}{0.827} \\
\hline .... creates awareness of entrepreneurship as a possible career choice & 0.868 & & \\
\hline .... motivates students to start a new business & 0.932 & & \\
\hline .... provides students with ideas to start a new business & 0.917 & & \\
\hline .... provides students with the knowledge needed to start a new business & 0.921 & & \\
\hline \multicolumn{2}{|l|}{ CS } & \multirow{5}{*}{0.867} & \multirow{5}{*}{0.621} \\
\hline In my country, green entrepreneurs are encouraged by an institutional structl & 0.751 & & \\
\hline My country's economy offers many opportunities for entrepreneurs & 0.815 & & \\
\hline Obtaining bank loans is quite difficult for entrepreneurs in my country & 0.752 & & \\
\hline The state laws of my country are adverse to the management of a company & 0.830 & & \\
\hline \multicolumn{2}{|l|}{ ESE } & \multirow{2}{*}{0.938} & \multirow{2}{*}{0.792} \\
\hline Creating and maintaining an ecological business is a task that I can do & 0.858 & & \\
\hline
\end{tabular}




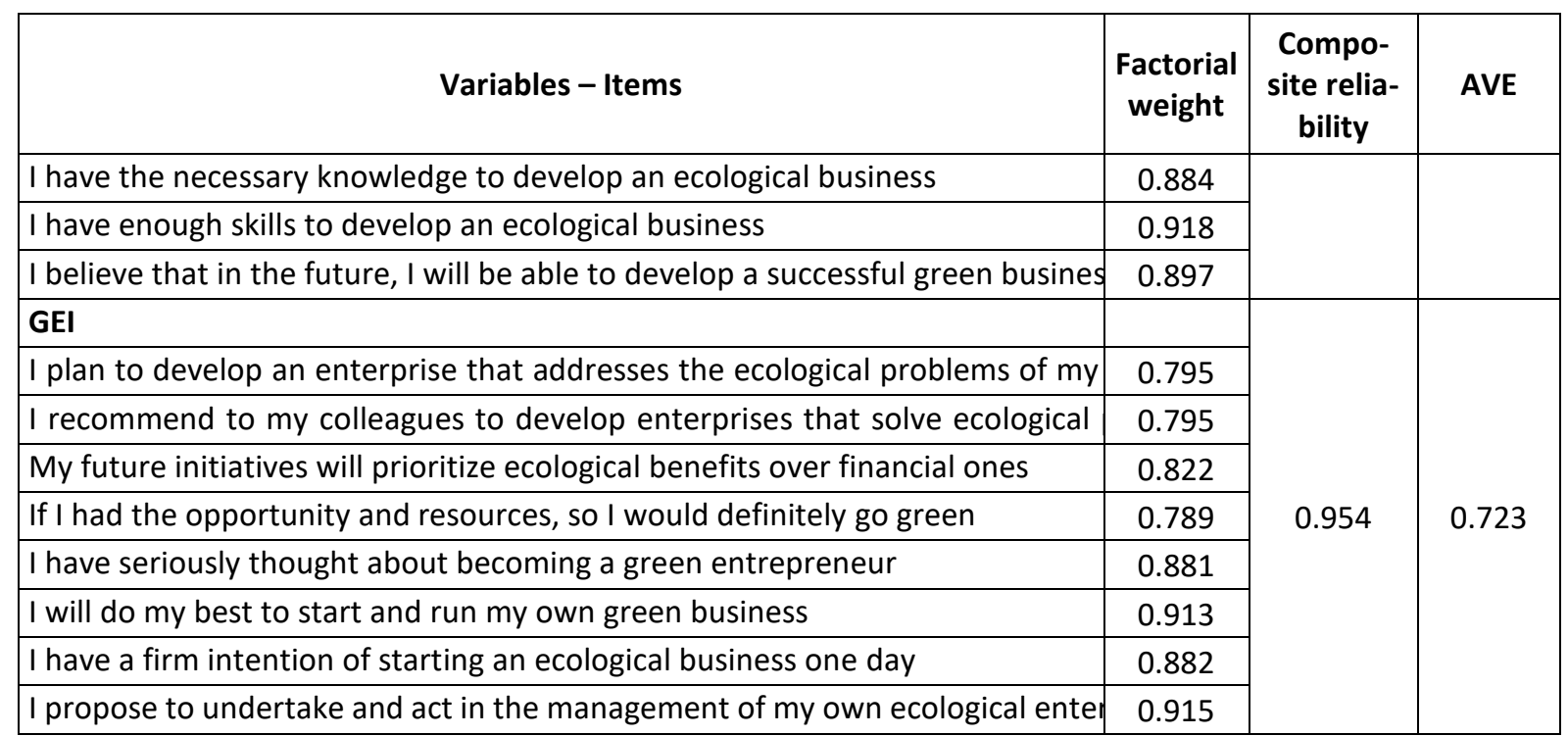

Source: own study.

\section{Discriminant validity}

Table 3 below shows that the evaluated data meet the Fornell-Larcker criterion; it means the variance extracted square root was higher than the correlations presented by one sub-scale against the rest of the sub-scales (Lopez-Odar et al., 2020).

Table 3. Discriminant validity

\begin{tabular}{|l|c|c|c|c|c|}
\hline Scales & $\begin{array}{c}\text { Institutional } \\
\text { support }\end{array}$ & $\begin{array}{c}\text { Country } \\
\text { support }\end{array}$ & $\begin{array}{c}\text { Education } \\
\text { development } \\
\text { support }\end{array}$ & $\begin{array}{c}\text { Entrepreneurial } \\
\text { self-efficacy }\end{array}$ & $\begin{array}{c}\text { Green entre- } \\
\text { preneurial in- } \\
\text { tention }\end{array}$ \\
\hline IS & $\mathbf{( 0 . 9 1 0 )}$ & & & & \\
\hline CS & 0.447 & $\mathbf{( 0 . 7 8 8 )}$ & & & \\
\hline EDS & 0.815 & 0.466 & $\mathbf{( 0 . 8 7 2 )}$ & & \\
\hline ESE & 0.372 & 0.308 & 0.368 & $\mathbf{( 0 . 8 9 0 )}$ & \\
\hline GEI & 0.386 & 0.375 & 0.387 & 0.757 & 0.851 \\
\hline
\end{tabular}

Source: own study.

\section{RESULTS AND DISCUSSION}

\section{Bootstrapping}

Bootstrapping Technique (5000 times) demonstrated that path coefficients were significant ( $p$ values <0.01; see Table 4).

Table 4. Trajectory coefficients (beta)

\begin{tabular}{|l|c|c|c|c|c|}
\hline \multicolumn{1}{|c|}{ Scales } & Original sample & Mean sample & Standard deviation & t-statistic & P \\
\hline $\mathrm{IS} \rightarrow \mathrm{ESE}$ & 0.183 & 0.188 & 0.099 & 2.845 & 0.012 \\
\hline $\mathrm{CS} \rightarrow \mathrm{ESE}$ & 0.158 & 0.164 & 0.063 & 2.528 & 0.016 \\
\hline EDS $\rightarrow$ ESE & 0.146 & 0.141 & 0.099 & 2.474 & 0.031 \\
\hline ESE $\rightarrow$ GEI & 0.757 & 0.758 & 0.039 & 19.264 & 0.000 \\
\hline
\end{tabular}

p-value $<0.01$.

Source: own study.

Figure 2 below presents the evaluation of the research model. We confirmed that - through ESE - EDS, IS, and CS positively influence GEI in international business students. 


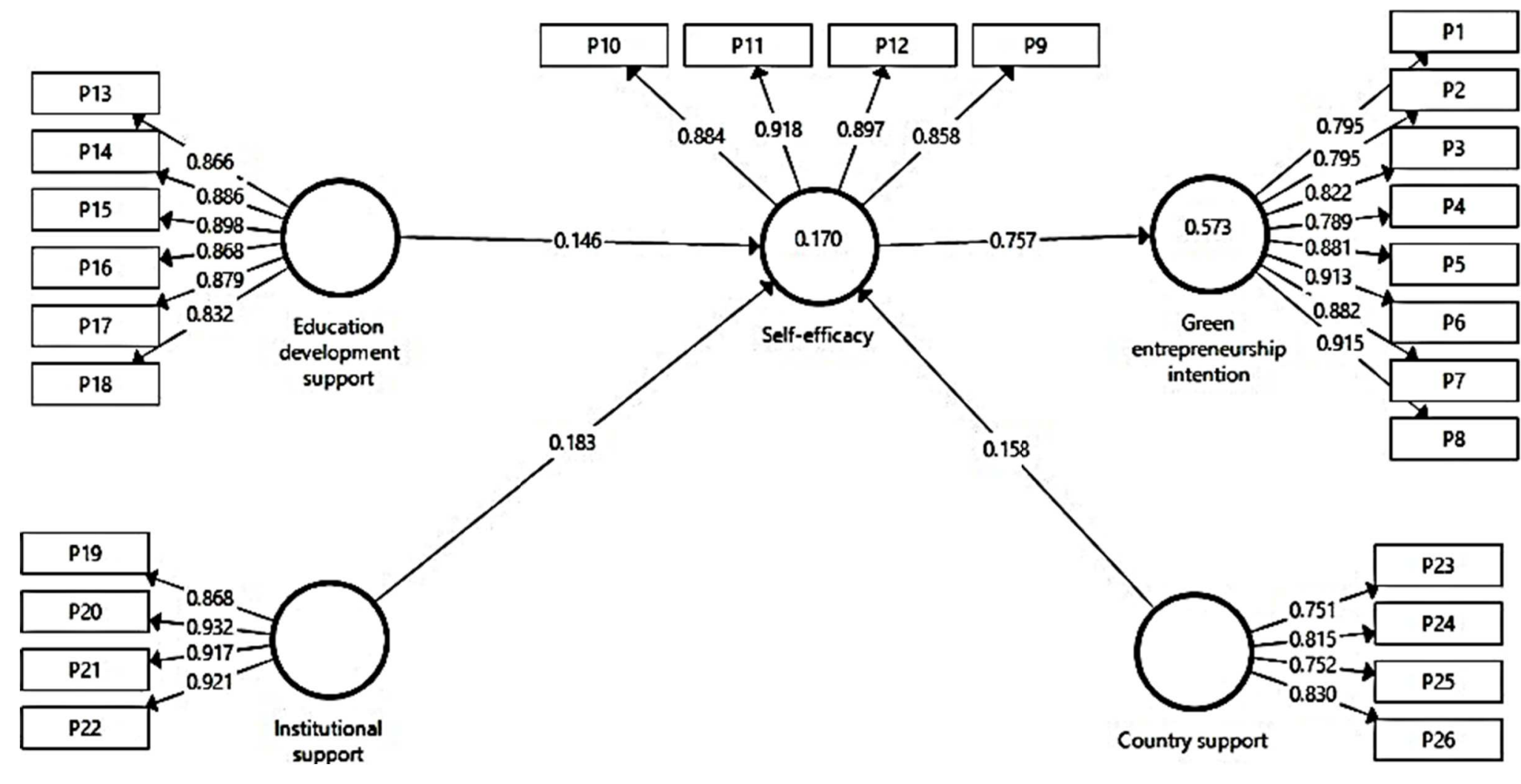

Figure 2. Research model tested

Source: own elaboration. 


\section{Hypotheses test}

Entrepreneurial development support had a positive influence of 0.146 over ESE. Thus, we confirmed hypothesis $\mathrm{H} 1$. Moreover, IS had a positive influence of 0.183 over ESE, which confirmed hypothesis $\mathrm{H} 2$. Furthermore, CS had a positive influence of 0.158 over ESE, thus confirming hypothesis $\mathrm{H} 3$. Finally, CS with EDS and IS explain 17\% of ESE. Entrepreneurial self-efficacy has a positive influence of 0.757 over $\mathrm{GEl}$, which confirms hypothesis $\mathrm{H} 4$.

\section{Discussion}

We evaluated the influence of education development support, institutional support, and country support through entrepreneurial self-efficacy over green entrepreneurial intention in international business students in Peru. The discriminant validity and reliability were verified to ensure that the employed questionnaire can be trusted.

The verified influence of IS on ESE agrees with the finding of Shi, Yao, and Wu (2019) who studied 374 Chinese university students, the study of Mozahem and Adlouni (2020) who examined in 560 university students from Lebanon, and with a study of 376 university students in Indonesia (Wardana et al., 2020). It is priceless to know if universities offer elective entrepreneurship courses because although there may be accelerators that can allow new ideas to gain in scale and become successful star-ups, a course with all its theoretical and practical components can doubtlessly give further training to students. Moreover, it is helpful that we can evidence if universities call for entrepreneurship projects and collaborate with companies so that students can gain entrepreneurial practice. A very unusual aspect - but a possibly revolutionary one - is to know if universities offer careers focused on entrepreneurship or offering postgraduate programs in entrepreneurship like the ones by the University of Melbourne (Melbourne, 2021) and Amsterdam Business School (School, 2021). Moreover, it is also relevant to confirm that universities organize conferences on entrepreneurship since, in this way, preliminary results of entrepreneurship efforts can be disseminated and contact with successful entrepreneurs can be generated, who can then present their experience and motivate students to become entrepreneurs.

The verified influence of IS on ESE is in line with the report by Burnette et al. (2019), another study of 109 undergraduate university students (van der Westhuizen \& Goyayi, 2019), but also with the findings by Cadenas, Cantú, Lynn, Spence, and Ruth (2020) in the USA, Shi et al. (2019) in China, and Elnadi and Gheith (2021) in Saudi Arabia. It is essential to know if the university has focused on creating awareness about entrepreneurship so that students can decide on entrepreneurship as a professional career at the end of their classes. Likewise, significant is the motivation that students may want to generate to start a new business. Among the most important aspects is knowledge whether the university provides systematic ways to generate new businesses based on entrepreneurship. In this sense, it is crucial that future researchers specifically ask whether universities have think tanks as those promoted by the University of Oxford (Oxford, 2021) and Harvard University (Harvard, 2021).

The influence of CS on ESE that was verified in the present study agrees with the study by Memon, Soomro Bahadur, and Shah (2019), who evaluated 564 university students from Pakistan, and with findings reported by Nowiński, Haddoud, Wach, and Schaefer (2020), who evaluated 360 university students in USA and 1054 university students in Poland. When entrepreneurship is evaluated, scholars usually test if students receive institutional support, but they very rarely evaluate the support and impulse given by governments for green entrepreneurship. Therefore, it is helpful to evaluate this support from the country, which also must modify specific laws and banks to promote investment in green enterprises and back loans at reasonable rates to encourage new green entrepreneurs. Jointly, CS, EDS, and IS explain $17 \%$ of ESE. This outcome is very relevant since it allows us to understand that these variables can make students feel they can conduct green ventures based on the knowledge obtained and the skills developed due to the support through courses, practices, and regulatory support. These aspects imbue students with great confidence to develop green ventures that contribute to the United Nations' SDGs.

The influence of ESE on green entrepreneurship intention demonstrated in the current study is like the one reported by Soomro et al. (2020), who studied 284 university students from Pakistan. We researched the intention of ecological entrepreneurship which will make this study be a point of 
reference for other Latin American inquiries. There is a significant growth of entrepreneurship, which can be an unbeatable opportunity to implement this type of entrepreneurship with an evident impact environment.

The outcomes obtained are like Bonnet et al. (2006), based on the similar influence of entrepreneurship programs with financing in the universities that are so relevant for new entrepreneurs who usually lack money. Moreover, our outcomes are like Futagami and Helms (2009), who recognize the university's role in providing counselling to students in the development of green entrepreneurship. The current study found data like those reported by Campelo Rodríguez (2013) and Opara (2013), who refer to the importance of the organization and support of green entrepreneurship projects, which allow students to develop their skills. Another important outcome is that, according to Eyo (2014), universities can offer technical support but not constant funds for developing green entrepreneurship.

Moreover, Nuringsih and Puspitowati (2017) report similar data about educational and structural support for developing green entrepreneurship, while Soomro et al. (2020) show outcomes in similar populations about the significant impact of education for sustainability on developing green entrepreneurship at universities.

\section{CONCLUSIONS}

The main contribution of this study is the demonstration that the variables we elaborated affect entrepreneurship intention. We found that our variables have a relevant impact on self-efficacy, which will be the first step for whom to have the intention of developing ecological enterprises. We were able to recognize that the literature is limited to green enterprises, so this study seeks to broaden this field of interest. The analysis is a strength of this article, as we find correlations between the same variables used in multivariate analyses by modelling structural equations using partial least squares (SEM PLS).

\section{Theoretical implications}

Studies in green entrepreneurship intention remain limited to a few countries, and not much is known about the factors that affect students. As a novelty, we incorporated into our model the support that students feel they receive from their governments, based on specific laws or programs directed towards students. We expect that in each country, this result may be different since different agendas are managed to support green entrepreneurship. By using SEM PLS, we found results that accurately confirm the relationship between the variables, and at the same time, we received a model that not only measures what universities do on campus through their courses or events but also conveys what are other incentives that motivate students towards green entrepreneurship.

We followed the TPB considering the dependent variable was the intention of behaviour; in this case, the intention of green entrepreneurship. The TPB has been beneficial to our study in putting together the research model since although we could measure behaviour - that is, current undertakings - it was very likely that students are not doing it today but potentially want to do it in the future. Therefore, the intention of green entrepreneurship was a pertinent variable that should be evaluated to see if it is constant in other situations. Likewise, this study followed the theory of social cognition with which we could demonstrate the critical role of ESE as the predictor of the intention of green entrepreneurship. Hence, we may provide a model proposal that takes the external aspects of the student to generate an influence on the conviction of developing a green enterprise, and that will finally translate into an express intention. External contexts are varied, and it is very important to be able to evaluate the influence, which in the present study is quite similar between the three independent variables. It should be considered that external contexts and elf-efficacy showed equal importance on the intention of entrepreneurship green.

\section{Practical implications}

Universities conduct their action plans annually, including the actions they will implement in most daily activities. Our results should attract the attention of universities so that they can recognize the elements that students seek to achieve in this way, the curricular changes, and the implementation of 
green entrepreneurship policy. The modification of universities' offer will facilitate their better support of students. At the same time, the offer can become attractive to new students since it will show that they improve universities integral programs that occur to achieve green undertakings among a significant number of students.

\section{Limitations and future scope}

The current study was only conducted among international business students, so the findings must be applied only to this group. It would be interesting to incorporate another group of students to test whether the relation between variables remains the same. Moreover, this study should be reproduced in other cities, but mainly in Latin American countries to help to discern the variables that influence the situation the most.

The future development of green entrepreneurship must be specifically evaluated to know what factors influenced entrepreneurs and recognize what changes the universities must emphasize among students for the development of green entrepreneurship.

\section{REFERENCES}

Alvarez-Risco, A., Del-Aguila-Arcentales, S., \& Diaz-Risco, S. (2018). Pharmacovigilance as a tool for sustainable development of healthcare in Peru. PharmacoVigilance Review, 10(2), 4-6.

Alvarez-Risco, A., Del-Aguila-Arcentales, S., Rosen, M. A., García-lbarra, V., Maycotte-Felkel, S., \& Martínez-Toro, G. M. (2021). Expectations and Interests of University Students in COVID-19 Times about Sustainable Development Goals: Evidence from Colombia, Ecuador, Mexico, and Peru. Sustainability, 13(6). https://doi.org/10.3390/su13063306

Alvarez-Risco, A., Estrada-Merino, A., Anderson-Seminario, M. d. I. M., Mlodzianowska, S., García-lbarra, V., Villagomez-Buele, C., \& Carvache-Franco, M. (2020). Multitasking behavior in online classrooms and academic performance: case of university students in Ecuador during COVID-19 outbreak. Interactive Technology and Smart Education, ahead-of-print(ahead-of-print). https://doi.org/10.1108/ITSE-08-2020-0160

Alvarez-Risco, A., Estrada-Merino, A., \& Perez-Luyo, R. (2020). Sustainable Development Goals in Hospitality Management. In H. Ruël \& A. Lombarts (Eds.), Sustainable Hospitality Management (Vol. 24, pp. 159-178). Bingley: Emerald Publishing Limited.

Alvarez-Risco, A., Mejia, C. R., Delgado-Zegarra, J., Del-Aguila-Arcentales, S., Arce-Esquivel, A. A., ValladaresGarrido, M. J., ... Yáñez, J. A. (2020). The Peru Approach against the COVID-19 Infodemic: Insights and Strategies. The American Journal of Tropical Medicine and Hygiene, 103(2), 583-586. https://doi.org/10.4269/ajtmh.20-0536

Ashraf, B. N. (2020). Economic impact of government interventions during the COVID-19 pandemic: International evidence from financial markets. Journal of Behavioral and Experimental Finance, 27, 100371. https://doi.org/10.1016/j.jbef.2020.100371

Bandura, A. (1992). Self-efficacy mechanism in psychobiologic functioning. In Self-efficacy: Thought control of action. (pp. 355-394). Washington, DC, US: Hemisphere Publishing Corp.

Banschbach, V. S., \& Letovsky, R. (2011). Teaming environmental biology and business administration seniors on "green" enterprise plans at Saint Michael's College, Vermont. Journal of Environmental Studies and Sciences, 1(3), 215-222. https://doi.org/10.1007/s13412-011-0036-x

Bergmann, H., Geissler, M., Hundt, C., \& Grave, B. (2018). The climate for entrepreneurship at higher education institutions. Research Policy, 47(4), 700-716. https://doi.org/10.1016/j.respol.2018.01.018

Bird, B. (1988). Implementing Entrepreneurial Ideas: The Case for Intention. Academy of Management Review, 13(3), 442-453. https://doi.org/10.5465/amr.1988.4306970

Bonnet, H., Quist, J., Hoogwater, D., Spaans, J., \& Wehrmann, C. (2006). Teaching sustainable entrepreneurship to engineering students: the case of Delft University of Technology. International Journal of Phytoremediation, 31(2), 155-167. https://doi.org/10.1080/03043790600566979

Burnette, J. L., Pollack, J. M., Forsyth, R. B., Hoyt, C. L., Babij, A. D., Thomas, F. N., \& Coy, A. E. (2019). A Growth Mindset Intervention: Enhancing Students' Entrepreneurial Self-Efficacy and Career Development. Entrepreneurship Theory and Practice, 44(5), 878-908. https://doi.org/10.1177/1042258719864293 
Cadenas, G. A., Cantú, E. A., Lynn, N., Spence, T., \& Ruth, A. (2020). A programmatic intervention to promote entrepreneurial self-efficacy, critical behavior, and technology readiness among underrepresented college students. Journal of Vocational Behavior, 116, 103350. https://doi.org/10.1016/j.jvb.2019.103350

Campelo Rodríguez, M. P. (2013). Rural development and entrepreneurship: The entrepreneurial potential of students of agricultural engineering of the University of Leon in Spain. Ilu, 18, 717-731. https://doi.org/10.5209/rev_HICS.2013.v18.44361

Chen, X., Zhang, S. X., Jahanshahi, A. A., Alvarez-Risco, A., Dai, H., Li, J., \& Ibarra, V. G. (2020). Belief in a COVID19 Conspiracy Theory as a Predictor of Mental Health and Well-Being of Health Care Workers in Ecuador: Cross-Sectional Survey Study. JMIR Public Health Surveill, 6(3), e20737. https://doi.org/10.2196/20737

Chrisman, J. J., Hynes, T., \& Fraser, S. (1995). Faculty entrepreneurship and economic development: The case of the University of Calgary. Journal of Business Venturing, 10(4), 267-281. https://doi.org/10.1016/08839026(95)00015-Z

Dill, D. D. (1995). University-industry entrepreneurship: The organization and management of American university technology transfer units. Higher Education, 29(4), 369-384. https://doi.org/10.1007/BF01383958

Elnadi, M., \& Gheith, M. H. (2021). Entrepreneurial ecosystem, entrepreneurial self-efficacy, and entrepreneurial intention in higher education: Evidence from Saudi Arabia. The International Journal of Management Education, 100458. https://doi.org/ 10.1016/j.ijme.2021.100458

Eyo, S. J. (2014). Japan's bioventures: Past, present and future. International Journal of Innovation and Technology Management, 11(5). https://doi.org/10.1142/S021987701450031X

Ferreira, A. d. S. M., Loiola, E., \& Guedes Gondim, S. M. (2017). Motivations, business planning, and risk management: Entrepreneurship among university students. INMR - Innovation \& Management Review, 14(2), 140-150.

Fichter, K., \& Tiemann, I. (2018). Factors influencing university support for sustainable entrepreneurship: Insights from explorative case studies. Journal of Cleaner Production, 175, 512-524. https://doi.org/10.1016/j.jclepro.2017.12.031

Fishbein, M., \& Ajzen, I. (1975). Belief, attitude, intention and behavior: An introduction to theory and research. Reading, MA: Addison-Wesley.

Fornell, C., \& Larcker, D. F. (1981). Evaluating Structural Equation Models with Unobservable Variables and Measurement Error. Journal of Marketing Research, 18(1), 39-50. https://doi.org/10.1177/002224378101800104

Futagami, S., \& Helms, M. M. (2009). Emerging female entrepreneurship in Japan: A case study of Digimom workers. Thunderbird International Business Review, 51(1), 71-85. https://doi.org/10.1002/tie.20216

Harvard. (2021). Think Tank Search. Retrieved from https://guides.library.harvard.edu/hks/think_tank_search on 19 June 2021

Hay, D. R. (1981). A Canadian university experience in technological innovation and entrepreneurship. Technovation, 1(1), 43-55. https://doi.org/10.1016/0166-4972(81)90006-7

Hills, G. E. (1988). Variations in University entrepreneurship education: An empirical study of an evolving field. Journal of Business Venturing, 3(2), 109-122. https://doi.org/10.1016/0883-9026(88)90021-3

Hopkins, T., \& Feldman, H. (1989). Changing Entrepreneurship Education: Finding the Right Entrepreneur for the Job. Journal of Organizational Change Management, 2(3), 28-40. https://doi.org/10.1108/09534818910145066

Huu-Phuong, T., \& Soo-Jiuan, T. (1990). Export Factoring: A Strategic Alternative for Small Exporters in Singapore. International Small Business Journal, 8(3), 49-57. https://doi.org/10.1177/026624269000800304

Johannisson, B. (1991). University training for entrepreneurship: Swedish approaches. Entrepreneurship and Regional Development, 3(1), 67-82. https://doi.org/10.1080/08985629100000005

Klofsten, M., \& Jones-Evans, D. (2000). Comparing Academic Entrepreneurship in Europe -The Case of Sweden and Ireland. Small Business Economics, 14(4), 299-309. https://doi.org/10.1023/A:1008184601282

Krueger, N. F., Reilly, M. D., \& Carsrud, A. L. (2000). Competing models of entrepreneurial intentions. Journal of Business Venturing, 15(5), 411-432. https://doi.org/10.1016/S0883-9026(98)00033-0

Kumar, R., \& Shukla, S. (2019). Creativity, Proactive Personality and Entrepreneurial Intentions: Examining the Mediating Role of Entrepreneurial Self-efficacy. Global Business Review, 0972150919844395. https://doi.org/10.1177/0972150919844395 
Laing, T. (2020). The economic impact of the Coronavirus 2019 (Covid-2019): Implications for the mining industry. The Extractive Industries and Society, 7(2), 580-582. https://doi.org/10.1016/j.exis.2020.04.003

Lamont, L. M. (1972). Entrepreneurship, technology, and the university. R\&D Management, 2(3), 119-123. https://doi.org/10.1111/j.1467-9310.1972.tb00977.x

Li, C., Murad, M., Shahzad, F., Khan, M. A. S., Ashraf, S. F., \& Dogbe, C. S. K. (2020). Entrepreneurial Passion to Entrepreneurial Behavior: Role of Entrepreneurial Alertness, Entrepreneurial Self-Efficacy and Proactive Personality. Frontiers in psychology, 11, 1611-1611. https://doi.org/10.3389/fpsyg.2020.01611

Liguori, E., \& Winkler, C. (2020). From Offline to Online: Challenges and Opportunities for Entrepreneurship Education Following the COVID-19 Pandemic. Entrepreneurship Education and Pedagogy, 3(4), 346-351. https://doi.org/10.1177/2515127420916738

Liñán, F., \& Chen, Y. W. (2009). Development and Cross-Cultural Application of a Specific Instrument to Measure Entrepreneurial Intentions. Entrepreneurship Theory and Practice, 33(3), 593-617. https://doi.org/10.1111/j.1540-6520.2009.00318.x

Lopez-Odar, D., Alvarez-Risco, A., Vara-Horna, A., Chafloque-Cespedes, R., \& Sekar, M. C. (2020). Validity and reliability of the questionnaire that evaluates factors associated with perceived environmental behavior and perceived ecological purchasing behavior in Peruvian consumers. Social Responsibility Journal, 16(3), 403417. https://doi.org/10.1108/SRJ-08-2018-0201

McMullan, W. E., Long, W. A., \& Graham, J. B. (1986). Assessing economic value added by university-based newventure outreach programs. Journal of Business Venturing, 1(2), 225-240. https://doi.org/10.1016/08839026(86)90016-9

Mei, H., Ma, Z., Jiao, S., Chen, X., Lv, X., \& Zhan, Z. (2017). The Sustainable Personality in Entrepreneurship: The Relationship between Big Six Personality, Entrepreneurial Self-Efficacy, and Entrepreneurial Intention in the Chinese Context. Sustainability, 9(9), 1649.

Melbourne, U. o. (2021). Master of Entrepreneurship.

Memon, M., Soomro Bahadur, A., \& Shah, N. (2019). Enablers of entrepreneurial self-efficacy in a developing country. Education + Training, 61(6), 684-699. https://doi.org/10.1108/ET-10-2018-0226

Meoli, A., Fini, R., Sobrero, M., \& Wiklund, J. (2020). How entrepreneurial intentions influence entrepreneurial career choices: The moderating influence of social context. Journal of Business Venturing, 35(3), 105982. https://doi:.org/10.1016/j.jbusvent.2019.105982

Moriano, J. A. (2005). El perfil psicosocial del emprendedor [The psychosocial profile of the entrepreneur]. Madrid: Consejo Económico y Social.

Mozahem, N. A., \& Adlouni, R. O. (2020). Using Entrepreneurial Self-Efficacy as an Indirect Measure of Entrepreneurial Education. The International Journal of Management Education, 100385. https://doi.org/10.1016/j.ijme.2020.100385

Neneh, B. N. (2019). From entrepreneurial intentions to behavior: The role of anticipated regret and proactive personality. Journal of Vocational Behavior, 112, 311-324. https://doi.org/10.1016/j.jvb.2019.04.005

Newman, A., Obschonka, M., Schwarz, S., Cohen, M., \& Nielsen, I. (2019). Entrepreneurial self-efficacy: A systematic review of the literature on its theoretical foundations, measurement, antecedents, and outcomes, and an agenda for future research. Journal of Vocational Behavior, 110, 403-419. https://doi.org/10.1016/j.jvb.2018.05.012

Nguyen, T. T. (2020). The impact of access to finance and environmental factors on entrepreneurial intention: The mediator role of entrepreneurial behavioural control. Entrepreneurial Business and Economics Review, 8(2), 127-140. https://doi.org/10.15678/EBER.2020.080207

Nowiński, W., Haddoud, M. Y., Wach, K., \& Schaefer, R. (2020). Perceived public support and entrepreneurship attitudes: A little reciprocity can go a long way! Journal of Vocational Behavior, 121, 103474. https://doi.org/10.1016/j.jvb.2020.103474

Nuringsih, K., \& Puspitowati, I. (2017). Determinants of eco entrepreneurial intention among students: Study in the entrepreneurial education practices. Advanced Science Letters, 23(8), 7281-7284. https://doi.org/10.1166/asl.2017.9351

Opara, U. L. (2013). Perspective: The role of universities in transforming African agriculture for economic development - Producing knowledge farmers and entrepreneurial leaders. International Journal of Postharvest Technology and Innovation, 3(2), 207-215. https://doi.org/10.1504/IJPTI.2013.055853 
Oxford, U. o. (2021). Think Tanks.

Quispe-Cañari, J. F., Fidel-Rosales, E., Manrique, D., Mascaró-Zan, J., Huamán-Castillón, K. M., ChamorroEspinoza, S. E., ... Mejia, C. R. (2021). Self-medication practices during the COVID-19 pandemic among the adult population in Peru: A cross-sectional survey. Saudi Pharmaceutical Journal, 29(1), 1-11. https://doi.org/10.1016/j.jsps.2020.12.001

Rauch, A., \& Hulsink, W. (2015). Putting Entrepreneurship Education Where the Intention to Act Lies: An Investigation Into the Impact of Entrepreneurship Education on Entrepreneurial Behavior. Academy of Management Learning \& Education, 14(2), 187-204. https://doi.org/10.5465/amle.2012.0293

Ringle, C. M., Wende, S., \& Becker, J. M. (2015). SmartPLS 3. Boenningstedt: SmartPLS GmbH.

Santos Susana, C., \& Liguori Eric, W. (2019). Entrepreneurial self-efficacy and intentions: Outcome expectations as mediator and subjective norms as moderator. International Journal of Entrepreneurial Behavior \& Research, 26(3), 400-415. https://doi.org/10.1108/IJEBR-07-2019-0436

School, A. B. (2021). Entrepreneurship.

Segal, N. S. (1986). Universities and technological entrepreneurship in Britain: Some implications of the Cambridge phenomenon. Technovation, 4(3), 189-204. https://doi.org/10.1016/0166-4972(86)90012-X

Shahab, Y., Chengang, Y., Arbizu Angel, D., \& Haider Muhammad, J. (2019). Entrepreneurial self-efficacy and intention: do entrepreneurial creativity and education matter? International Journal of Entrepreneurial Behavior \& Research, 25(2), 259-280. https://doi.org/10.1108/IJEBR-12-2017-0522

Shi, L., Yao, X., \& Wu, W. (2019). Perceived university support, entrepreneurial self-efficacy, heterogeneous entrepreneurial intentions in entrepreneurship education: The moderating role of the Chinese sense of face. Journal of Entrepreneurship in Emerging Economies, 12(2), 205-230. https://doi.org/10.1108/JEEE-04-2019-0040

Soomro, B. A., Ghumro, I. A., \& Shah, N. (2020). Green entrepreneurship inclination among the younger generation: An avenue towards a green economy. Sustainable Development, 28(4), 585-594. https://doi.org/10.1002/sd.2010

Soria-Barreto, K., Zúñiga-Jara, S., \& Ruiz Campo, S. (2016). Determinantes de la intención emprendedora: nueva evidencia. Interciencia, 41(5), 325-329.

Tajvidi, R., \& Tajvidi, M. (2020). The growth of cyber entrepreneurship in the food industry: virtual community engagement in the COVID-19 era. British Food Journal.

Tamkivi, R. (1999). Support Structures for Innovation and Research-Based Entrepreneurship in Estonia. Industry and Higher Education, 13(1), 46-53. https://doi.org/10.1177/095042229901300107

Udayanan, P. (2019). The role of self-efficacy and entrepreneurial self-efficacy on the entrepreneurial intentions of graduate students: A study among omani graduates. Entrepreneurial Business and Economics Review, 7(4), 7-20. https://doi.org/10.15678/EBER.2019.070401

van der Westhuizen, T., \& Goyayi, M. J. (2019). The influence of technology on entrepreneurial self-efficacy development for online business startup in developing nations. The International Journal of Entrepreneurship and Innovation, 21(3), 168-177. https://doi.org/10.1177/1465750319889224

Wardana, L. W., Narmaditya, B. S., Wibowo, A., Mahendra, A. M., Wibowo, N. A., Harwida, G., \& Rohman, A. N. (2020). The impact of entrepreneurship education and students' entrepreneurial mindset: the mediating role of attitude and self-efficacy. Heliyon, 6(9), e04922. https://doi.org/10.1016/j.heliyon.2020.e04922

Wegner, D., Thomas, E., Teixeira Eduardo, K., \& Maehler Alisson, E. (2019). University entrepreneurial push strategy and students' entrepreneurial intention. International Journal of Entrepreneurial Behavior \& Research, 26(2), 307-325. https://doi.org/10.1108/IJEBR-10-2018-0648

WHO. (2021). WHO Coronavirus Disease (COVID-19) Dashboard. Retrieved from https://covid19.who.int/ on 19 June 2021

Yan, J., Kim, S., Zhang, S. X., Foo, M.-D., Alvarez-Risco, A., Del-Aguila-Arcentales, S., \& Yáñez, J. A. (2021). Hospitality workers' COVID-19 risk perception and depression: A contingent model based on transactional theory of stress model. International Journal of Hospitality Management, 95, 102935. https://doi.org/10.1016/j.ijhm.2021.102935

Yáñez, J. A., Afshar Jahanshahi, A., Alvarez-Risco, A., Li, J., \& Zhang, S. X. (2020). Anxiety, Distress, and Turnover Intention of Healthcare Workers in Peru by Their Distance to the Epicenter during the COVID-19 Crisis. The American Journal of Tropical Medicine and Hygiene, 103(4), 1614-1620. https://doi.org/10.4269/ajtmh.20-0800 
Yáñez, J. A., Alvarez-Risco, A., \& Delgado-Zegarra, J. (2020). Covid-19 in Peru: from supervised walks for children to the first case of Kawasaki-like syndrome. BMJ, 369, m2418. https://doi.org/10.1136/bmj.m2418

Zhang, S. X., Chen, J., Afshar Jahanshahi, A., Alvarez-Risco, A., Dai, H., Li, J., \& Patty-Tito, R. M. (2021). Succumbing to the COVID-19 Pandemic-Healthcare Workers Not Satisfied and Intend to Leave Their Jobs. International Journal of Mental Health and Addiction. https://doi.org/10.1007/s11469-020-00418-6

Zhang, S. X., Sun, S., Afshar Jahanshahi, A., Alvarez-Risco, A., Ibarra, V. G., Li, J., \& Patty-Tito, R. M. (2020). Developing and testing a measure of COVID-19 organizational support of healthcare workers - results from Peru, Ecuador, and Bolivia. Psychiatry Research, 291, 113174. https://doi.org/10.1016/j.psychres.2020.113174 


\section{Authors}

The contribution of each author is equal to $25 \%$

AAR, SM, UZR - conceptualization AAR, SDAA - literature review, AAR - methodology, AAR, SDAA, - calculations, AAR, SM, UZR, SDAA - discussion.

\section{Aldo Alvarez-Risco}

PhD in Administration (2020, Universidad Autónoma de Nuevo León, Mexico); Professor at the Career of International Business, Universidad de Lima. His research interests include sustainability, international business, entrepreneurship, and circular economy.

Correspondence to: Aldo Alvarez-Risco, Universidad de Lima, Avenida Javier Prado Este 4600, Santiago de Surco, Lima, Peru, e-mail: aralvare@ulima.edu.pe

ORCID (1) http://orcid.org/0000-0003-0786-6555

\section{Sabina Mlodzianowska}

PhD in Economics (2008, University of Gdańsk, Poland); Director of Operations and Project Management Master Program at the Graduate School and Professor at the International Business Program, Universidad de Lima. Her research interests include mining, international business, sustainability and entrepreneurship.

Correspondence to: Sabina Mlodzianowska, Universidad de Lima, Avenida Javier Prado Este 4600, Santiago de Surco, Lima, Peru, e-mail: email: smlodzia@ulima.edu.pe

ORCID (1) http://orcid.org/0000-0002-9649-2024

\section{Ulises Zamora Ramos}

Master's degree in International Commerce (2014) from Universidad Nacional Mayor de San Marcos, Peru; Professor in International Business, Universidad ESAN. His research interests include international business, international marketing, and entrepreneurship.

Correspondence to: Ulises Zamora Ramos, Universidad ESAN, Alonso de Molina, 1652, Monterrico, Surco, Lima, Peru, e-mail: uzamora@esan.edu.pe

ORCID (1) http://orcid.org/0000-0001-8937-5076

\section{Shyla Del-Aguila-Arcentales}

Master's degree in Industrial Pharmacy (2017) from Universidad Nacional Mayor de San Marcos, Peru; Professor at Escuela Nacional de Marina Mercante "Almirante Miguel Grau" in Peru. Her research interests include sustainability, entrepreneurship, international business, e-commerce, and digital business.

Correspondence to: Shyla Del-Aguila-Arcentales, Escuela Nacional de Marina Mercante "Almirante Miguel Grau", Avenida Progreso 632, Callao, Lima, Peru, e-mail: sdelaguila@enamm.edu.pe ORCID (1) http://orcid.org/0000-0002-9532-6462

\section{Conflict of Interest}

The authors declare that the research was conducted in the absence of any commercial or financial relationships that could be construed as a potential conflict of interest.

\section{Copyright and License}

This article is published under the terms of the Creative Commons

Attribution - NoDerivs (CC BY-ND 4.0) License

http://creativecommons.org/licenses/by-nd/4.0/

Published by Cracow University of Economics - Krakow, Poland 